CHEMICAL SEPARATIONS PROCESSES

FOR PLUTONIUM AND URANIUM

(TID-4500, 16th Ed.)

\title{
PHYSICAL PROPERTIES OF URANIUM PROCESS SOLUTIONS
}

by

Robert S. Ondrejcin

October 1961

E. I. du Pont de Nemours \& Co.

Explosives Department - Atomic Energy Division

Technical Division - Savannah River Laboratory

Printed for

The United States Atomic Energy Commission

Contract A.T $(07-2)-1$

Approved by

H. M. Kelley, Research Manager

Analytical Chemistry Division 


\section{DISCLAIMER}

This report was prepared as an account of work sponsored by an agency of the United States Government. Neither the United States Government nor any agency Thereof, nor any of their employees, makes any warranty, express or implied, or assumes any legal liability or responsibility for the accuracy, completeness, or usefulness of any information, apparatus, product, or process disclosed, or represents that its use would not infringe privately owned rights. Reference herein to any specific commercial product, process, or service by trade name, trademark, manufacturer, or otherwise does not necessarily constitute or imply its endorsement, recommendation, or favoring by the United States Government or any agency thereof. The views and opinions of authors expressed herein do not necessarily state or reflect those of the United States Government or any agency thereof. 


\section{DISCLAIMER}

Portions of this document may be illegible in electronic image products. Images are produced from the best available original document. 


\begin{abstract}
Integral diffusion coefficients, viscosities, densities, and surface tensions were measured for the aqueous uranyl nitrate - nitric ac1d aluminum nitrate system. The variation of the uranium diffusion coefficlent was determined as a function of uranium concentration, nitric acid concentration, and temperature.
\end{abstract}




\section{CONTENTS}

$\underline{\text { Page }}$

Introduction

Summary

Discussion

Apparatus

Procedures

Results

Integral Diffusion Coefficients and Cell Constants

Bibliography

\section{LIST OF TABLES AND FIGURES}

$\underline{T a b l e}$

I Calibration of Diffusion Cells 9

II Integral Diffusion Coefficients and Viscosities 9

II Density and Surface Tension 12

\section{Figure}

1 Diffusion Cell 6

2 Diffusion Coefficlent of Uranyl Nitrate in Water vs. Temperature

3 Diffusion Coefficient of $0.200 \mathrm{M}$ Uranyl Nitrate vs. Nitric Acid Concentration at $25^{\circ} \mathrm{C}$ 


\section{PHYSICAL PROPERTIES OF URANIUM PROCESS SOLUTIONS}

\section{INTRODUCTION}

The process of solvent extraction of uranium from an aqueous phase involves a diffusion mechanism. Data on the diffusion coefficients of uranium salts are limited in number and the concentrations reported $(1,2,3)$ are frequently lower than those of interest in the separations processes. For a given set of conditions, the diffusion coefficients quoted in the literature vary by as much as a factor of two. Since a rational interpretation of mass transfer in turbine contactors was desired, a more precise set of values had to be obtained over the concentration range of interest.

The work described here covers the measurement of diffusion coefficients of uranyl nitrate, nitric acid, and aluminum nitrate in the concentration range normally encountered in the separations processes for natural and enriched uranium. Measurements were made by means of a porous diaphragm cell with magnetic stirring $(4,5)$.

The variation of diffusion (D) as a function of solution viscosity is expressed in the Stokes-Einstein relationship and has been treated by others ${ }^{(6)}$; therefore, measurements of viscosity $(\mu)$ were made on all solutions prior to diffusion. Measurements of density $(p)$ and surface tension were also made because the data would be useful in designing extraction equipment. With the avallable information the Schmidt group $(\mu / \rho D)$ can be determined for use in calculations of fluid flow and mass transfer where the diffusion coefficient is seldom used alone.

\section{SUMMARY}

Measurements of the integral diffusion coefficlents, viscosities, densities, and surface tensions were made on solutions of uranyl nitrate, nitric acld, and aluminum nitrate. The range of concentrations included those normally found in the separations processes for irradiated natural and enriched uranium.

Graphs are presented showing variations in the diffusion coefficient of uranium nitrate with changes in temperature and nitric acld concentration. 


\section{DISCUSSION}

The diffusion coefficients that are published for uranium salts are based on two different types of measurements. The flrst type is the measurement of the self-diffusion or differential diffusion coefficlent, normally based on the capillary tube technique first developed by Anderson and Saddington $(7)$. In this method radioisotopes are used and the diffusion of an 1sotope, in this case uranium (1,2), is measured in the absence of a concentration gradient. The second type of measurement involves a concentration gradient. The value obtained is an average for the concentration studied and is known as the integral diffusion coefficient. The change in concentration is normally measured by light refraction or interference (8), conductance, or chemical means after diffusion through a diaphragm (3). The diaphragm cell is a closed glass tube separated into two compartments by a sintered glass frit. Diffusion occurs through the frit from a solution of high concentration to a solution of lower concentration. Most often the salts are diffused into some inftially pure solvent.

The average length of the diffusion path is determined by the average pore size, the thickness of the frit, and the laminar layer formed on either side of the frit. Physical measurement of this path length $1 \mathrm{~s}$ not practical; therefore, the cell is calibrated with a standard of known diffusion coefficient.

Much of the early work is unreliable because of the problem of providing adequate agitation in the cell. Early measurements were based on density stirring. The solution with the highest density was placed in the upper compartment and allowed to diffuse downward. Bulk streaming occurred if the frit had a few large pores, and the thickness of the laminar layer varied depending on the viscosities of the liquids in the compartments. In another method of stirring, solid bodies were used $^{(\theta)}$ that sank as the cell was rotated. Several papers have appeared in which magnetic stirring was used $(10,12,12)$. With this system, one magnetized bar rests on the frit in the top compartment and another floats agalnst the bottom of the frit in the bottom compartment. The bars are moved by a rotating magnetic fleld. Th1s method eliminates the formation of laminar layers.

Diffusion coefficients of electrolytes in simple systems usually agree well with theory at concentrations below $0.01 \mathrm{M}^{(13)}$, but of ten depart radically at higher concentrations. In theoretical calculations the diffusion coefficient is a function of such quantities as transference numbers, conductivity, electrophoretic contributions, and concentration $\{1\}$. Consequently, integral diffusion coefficients must be measured at concentrations above $0.01 \mathrm{M}$ or when more than two components are present. 


\section{APPARATUS}

A typical cell is shown in Figure 1. The cell compartments were made of "Pyrex" glass of 28-mm OD. The compartments were approximately $50 \mathrm{mI}$ in volume and were separated by a frit $25 \mathrm{~mm}$ in diameter with a 4-5.5 micron nominal maximum pore size. The upper and lower compartments were closed with a 10/30 stopper and a "Teflon" stopcock, respectively. The stirrers were "Teflon"-coated magnet1c stirring bars attached to glass shafts by means of speclal "Teflon" collars. This arrangement prevented the stirrers from rubbing against the frit, as often occurs in this type of design $(10,11,12)$.

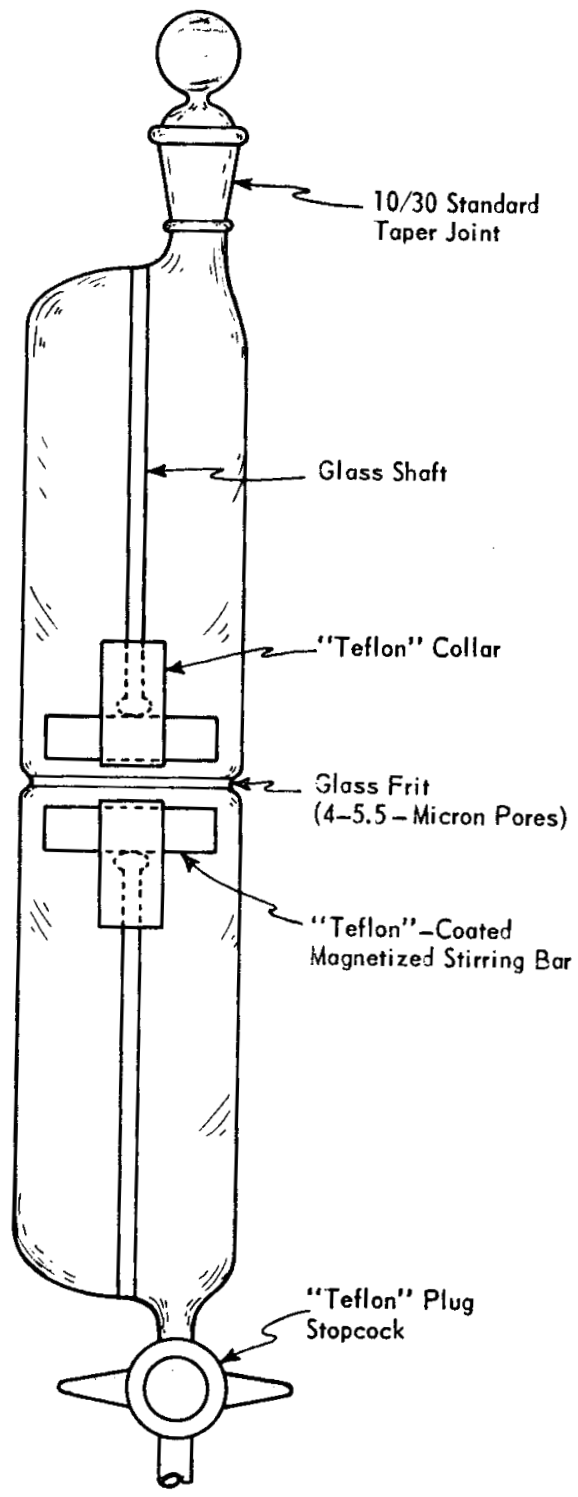

FIG. I DIFFUSION CELL 
The solution was stirred by DC magnetization and demagnetization of four successive palrs of colls, which produced a rotating magnetic field. The field could be varied from 40 to $200 \mathrm{rpm}$ by controlling the speed of the switching motor. The colls were mounted on a metal ring and were large enough to operate both the upper and lower stirrers. Each set of colls was encapsulated in "Kold-Weld"* resin, so that the colls could be immersed in a water bath regulated at 25,40 and $55^{\circ} \mathrm{C}$ to $\pm 0.05^{\circ} \mathrm{C}$.

Viscosities were measured at these temperatures with a series of Cannon-Fenske viscometers according to ASTM method D445-53T. A Christian Becker spec1fic gravity balance, Model $S G-1$ and a Cenco-Du Noüy tensiometer with a $6-\mathrm{cm}$ platinum ring were used to measure specific gravity and surface tension, respectively, in a speclal cell through which water from the water bath was circulated at the specified temperatures.

\section{PROCEDURES}

Prior to the preparation of multicomponent solutions, a solution of each component was standardized. Uranium solutions were prepared from uranyl nitrate and analyzed by titration against a standardized ceric solution. Nitric acid was analyzed by acid-base titration and the aluminum nitrate solution was analyzed by precipitation with 8-hydroxyquinoline. The analyzed solutions were then quant1tat1vely combined and diluted to produce the desired final solutions.

After each diffusion experiment, uranium was analyzed by the same method that was used prior to diffusion. The total acidity of the samples containing uranium or aluminum was determined potentiometrically. Potassium fluoride was used as a complexing agent for uranium and aluminum in these samples. Aluminum was determined as previously described after it was separated from uranium by ion exchange ${ }^{(15)}$.

Before the diffusion cell was fllled, all solutions were degassed and brought to the temperature of the water bath. Dissolved gases can form bubbles in the frit and partially block the pores during diffusion. Expansion or contraction of the solutions in the diffusion cell would cause bulk streaming through the frit.

The lower compartment was inltially filled by partially evacuating the ent1re cell, opening the stopcock, and drawing in solution until the frit was filled. Some solution was allowed to enter the upper compartment to drive any entrapped gases from the pores of the frit. Excess solution on the frit was removed with a small polyethylene tube under vacuum. The upper compartment was then filled with a quantity of pure solvent equal to the volume of the lower compartment.

\footnotetext{
* Product of Precision Dental Mfg. Co.
} 
After the filled cell was immersed in the water, a concentration gradient was allowed to develop in the frit ${ }^{(3)}$. This required about four hours. The cell was then removed, the solution in the upper compartment was emptied with a polyethylene tube under vacuum, and the compartment was rinsed and filled with new solvent. The solution in the lower compartment was withdrawn in the same manner and replaced with new standard solution. During these operations it was necessary to exercise care to prevent disturbing the concentration gradient in the frit. This procedure reduced uncertainties in the initial concentrations in the lower compartment and allowed a determination of the exact starting time.

An initial run was made to determine the length of time required for 20-25\% of the solute molecules to diffuse. The runs used for measurement were then made, and the solute concentration was measured only at the end of the run. A diffusion run normally lasted from $72-240$ hours.

\section{RESULTS}

\section{INTEGRAL DIFFUSION COEFFICIENTS AND CELL CONSTANTS}

The integral diffusion coefficient can be expressed by Equation $(1)^{(3,16)}$.

$$
\bar{D}=\frac{I}{\beta t} \ln \frac{\Delta c_{t}}{\Delta c_{0}}
$$

where

$$
\begin{aligned}
\Delta c_{0}= & \text { concentration difference between compartments } \\
& \text { at time } 0 \\
\Delta c_{t}= & \text { concentration difference between compartments } \\
& \text { at time } t \\
\bar{D}= & \text { integral diffusion coefficient } \\
t= & \text { time } \\
B= & a \text { diffusion cell constant }
\end{aligned}
$$

In diffusion measurements all solutions must be analyzed accurately because smallerrors in concentration produce a large change in the value of $\ln \frac{\Delta c_{t}}{\Delta c_{0}}$. The limiting factor in the value of $\bar{D}$ is the accuracy of the determination of solute concentrations.

The value of $\bar{D}$ is well known for potassium chloride at $25^{\circ} \mathrm{C}$ when $25 \%$ of a $0.200 \mathrm{~m}$ solution diffuses (12). The diffusion cells were calibrated with this standard. The $\mathrm{KCl}$ solutions were analyzed by titration with standardized silver nitrate and dichlorofluorescein indicator. 
It has been reported $(3,10)$ that the cell constant will vary with stirring speed until laminar layer formation is destroyed on both sides of the frit. Observations showed that the value of $\bar{D}$ for potassium chloride appeared to vary until a stirring speed of $70-90 \mathrm{rpm}$ was reached. Variations in the speed necessary to reach a constant $\bar{D}$ were probably dependent upon slight varlations in the surfaces of the frits. From the minimum stirring speed required for a constant $\bar{D}$ value to $150 \mathrm{rpm}$, there was no varlation in the value of $\bar{D}$. Diffusions were made with stirrer speeds of $12.5-130 \mathrm{rpm}$.

Table I shows typical results from calibrations of cells w1th $0.200 \mathrm{M}$ potassium chloride.

$\underline{\text { TAFIE I }}$

Calibration of Diffusion Cells

\begin{tabular}{|c|c|c|c|}
\hline Cell & B, Ce11 & Constan & $t,-\mathrm{cm}^{-2}$ \\
\hline No. & Run I & Run II & Avg. \\
\hline 1 & 0.0395 & 0.0399 & 0.0397 \\
\hline 2 & 0.0762 & 0.0758 & 0.0760 \\
\hline 3 & 0.0640 & 0.0626 & 0.0633 \\
\hline 4 & 0.0511 & 0.0506 & 0.0508 \\
\hline
\end{tabular}

The diffusion coefficlents quoted in Table II are for the multiple component systems and not for single components in a solvent unless specified as such.

The average coefficient of variation of uranium diffusion coefficients is $4.8 \%$. The value of $n$ varied from 2 to 4 .

TABIE II

Integra1 Diffusion Coerficients and V1scosities

\begin{tabular}{|c|c|c|c|c|c|c|c|}
\hline \multirow{2}{*}{$\begin{array}{c}\text { Uranyl } \\
\text { N1trate, } \\
M \\
\end{array}$} & \multirow{2}{*}{$\begin{array}{l}\text { Nitric } \\
\text { Ac1d, } \\
\mathrm{M} \\
\end{array}$} & \multirow{2}{*}{$\begin{array}{l}\text { Aluminum } \\
\text { N1trate, } \\
\text { M } \\
\end{array}$} & \multirow{2}{*}{$\begin{array}{c}\text { Temp., } \\
{ }^{\circ} \mathrm{C} \\
\end{array}$} & \multirow{2}{*}{$\begin{array}{l}\text { Viscosity, } \\
\text { m1111po1ses }\end{array}$} & \multicolumn{3}{|c|}{ Diffusion Coeffletent, $\mathrm{cm}^{2} / \mathrm{sec}$} \\
\hline & & & & & Urany 1 N1trate & N1tr1c Ac1d & Aluminum N1trate \\
\hline 0.0200 & - & - & 25.0 & 9.15 & $7.8 \times 10^{-6}$ & - & - \\
\hline 0.200 & - & - & 25.0 & 10.1 & $8.3 \times 10^{-6}$ & - & - \\
\hline 2.00 & - & - & 25.0 & 30.5 & $8.4 \times 10^{-6}$ & - & - \\
\hline 0.200 & 0.100 & - & 25.0 & 10.2 & $6.1 \times 10^{-6}$ & $9.5 \times 10^{-5}$ & - \\
\hline 0.200 & 1.00 & - & 25.0 & 10.3 & $4.6 \times 10^{-6}$ & $4.0 \times 10^{-5}$ & - \\
\hline 0.200 & 3.00 & - & 25.0 & 11.3 & $4.4 \times 10^{-6}$ & $3.8 \times 10^{-5}$ & - \\
\hline 0.200 & - & 0.500 & 25.0 & 14.6 & $9.6 \times 10^{-6}$ & - & $9.2 \times 10^{-6}$ \\
\hline 0.200 & - & 1.00 & 25.0 & 22.2 & $10.2 \times 10^{-6}$ & - & $9.4 \times 10^{-6}$ \\
\hline 0.200 & 1.00 & 0.500 & 25.0 & 15.0 & $8.9 \times 10^{-6}$ & $7.8 \times 10^{-5}$ & $4.8 \times 10^{-6}$ \\
\hline 0.200 & 1.00 & 1.00 & 25.0 & 23.6 & $11.6 \times 10^{-6}$ & $9.9 \times 10^{-5}$ & $7.0 \times 10^{-6}$ \\
\hline 0.200 & 3.00 & 0.500 & 25.0 & 16.7 & $8.9 \times 10^{-6}$ & $4.5 \times 10^{-5}$ & $4.4 \times 10^{-6}$ \\
\hline 0.200 & 3.00 & 1.00 & 25.0 & 26.4 & $9.9 \times 10^{-6}$ & $5.2 \times 10^{-5}$ & $5.3 \times 10^{-6}$ \\
\hline 0.0200 & - & - & 40.0 & 6.78 & $13.0 \times 10^{-6}$ & - & - \\
\hline 0.200 & - & - & 40.0 & 7.43 & $13.6 \times 10^{-6}$ & - & - \\
\hline 0.0200 & - & - & 55.0 & 5.21 & $13.8 \times 10^{-6}$ & - & - \\
\hline 0.200 & - & - & 55.0 & 5.76 & $14.8 \times 10^{-6}$ & - & _ \\
\hline
\end{tabular}


The alffusion coefficients of uranium nitrate in the absence of aluminum nitrate decreased with increased nitric acid concentration, which indicates complex Ion formation. Aluminum nitrate increased the diffusion coefficient of uranium in the absence of nitric acid. In the concentration ranges studied, the aluminum nitrate taken alone was more effective in increasing the diffusion coefficlent of uranium than the nitric acid was in decreasing the diffusion coefficient of uranium. With the introduction of aluminum nitrate or nitric acid to the diffusion solutions, the diffusion coefficients did not continue to follow the original trends consistentiy.

Figure 2 shows the increase in diffusion coefficient at 0.0200 and $0.200 \mathrm{M}$ uranium nitrate with temperature. The relationship of the diffusion coefficient of $0.2 \mathrm{M}$ uranium nitrate and the concentration of nitric acid from 0.001 to $3 \mathrm{M}$ is shown in Figure 3 . The small increases of the integral diffusion coefflcient at $25^{\circ} \mathrm{C}$ with increasing uranium nitrate concentration over a range of 0.02 to $2 \mathrm{M}$ are shown in Table II.

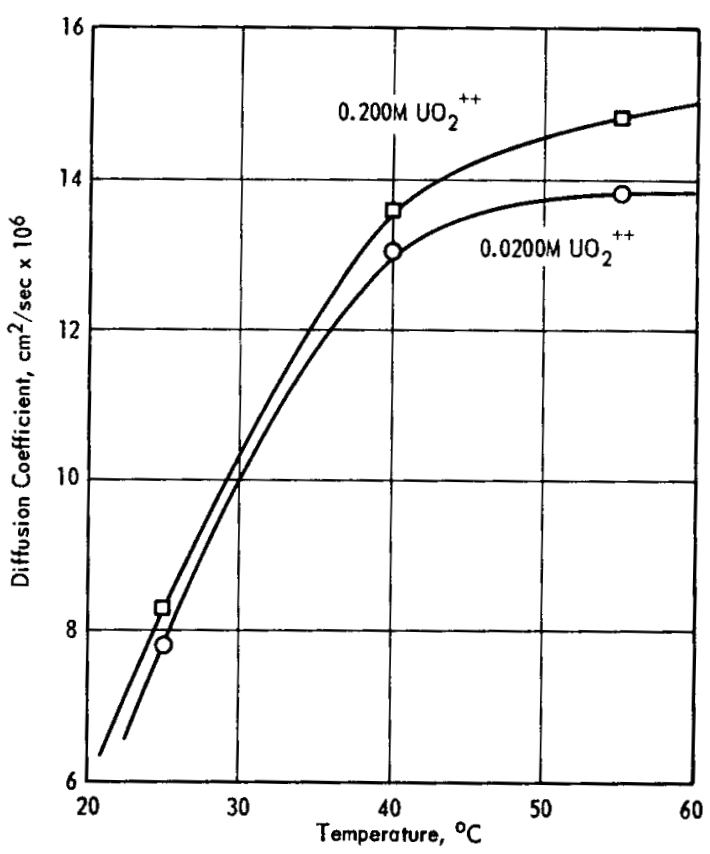

FIG. 2 DIFFUSION COEFFICIENT OF URANYL NITRATE IN WATER VS. TEMPERATURE

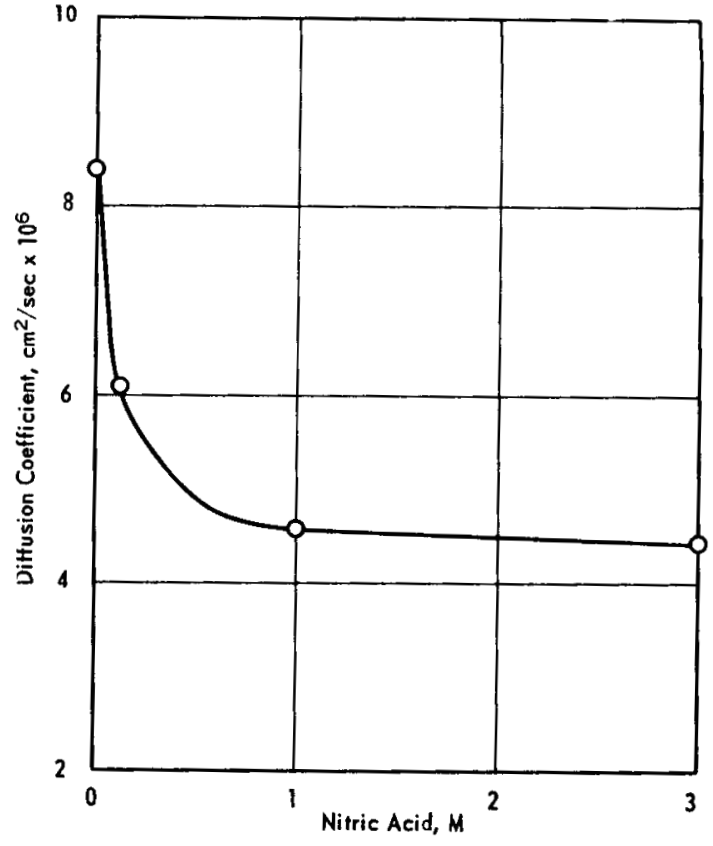

FIG. 3 DIFFUSION COEFFICIENT OF $0.200 \mathrm{M}$ URANYL NITRATE VS. NITRIC ACID CONCENTRATION AT $25^{\circ} \mathrm{C}$ 
VISCOSITIES, DENSITIES, AND SURFACE TENSIONS

The problem of correlation of diffusion coefficlents with viscosities can be approached in two different manners. The classical method uses the Stokes-Einstein relationship, which assumes that the medium is continuous and the diffusing molecule is large. In an alternative approach that depends on the absolute reaction rate theory, diffusion and viscous flow are considered to be very similar. The assumption is made that the diffusing molecules and the medium have approximately the same dimensions. Theoretical treatment of these methods of approach is ava1lable in the literature ${ }^{(14)}$.

Table III shows the values of the density and surface tension for the solutions of uranyl nitrate, nitric acid, and aluminum nitrate.

\section{TABLE III}

Density and Surface Tension

\begin{tabular}{|c|c|c|c|c|c|}
\hline $\begin{array}{c}\text { Uranyl } \\
\text { N1trate, } \\
\text { M } \\
\end{array}$ & $\begin{array}{l}\text { Nitric } \\
\text { Ac1d, } \\
\text { M }\end{array}$ & $\begin{array}{c}\text { Aluminum } \\
\text { N1trate, } \\
M \\
\end{array}$ & $\begin{array}{c}\text { Temp., } \\
{ }^{\circ} \mathrm{C} \\
\end{array}$ & $\begin{array}{c}\text { Density, } \\
\mathrm{g} / \mathrm{ml}\end{array}$ & $\begin{array}{l}\text { Surface } \\
\text { Tension, } \\
\text { dynes/cm }\end{array}$ \\
\hline 0.0200 & - & - & 25.0 & 1.004 & 73 \\
\hline 0.200 & - & - & 25.0 & 1.062 & 73 \\
\hline 2.00 & - & - & 25.0 & 1.641 & 77 \\
\hline 0.200 & 0.100 & - & 25.0 & 1.067 & 70 \\
\hline 0.200 & 1.00 & - & 25.0 & 1.096 & 70 \\
\hline 0.200 & 3.00 & - & 25.0 & 1.162 & 70 \\
\hline 0.200 & - & 0.500 & 25.0 & 1.143 & 75 \\
\hline 0.200 & - & 1.00 & 25.0 & 1.218 & 74 \\
\hline 0.200 & 1.00 & 0.500 & 25.0 & 1.175 & 45 \\
\hline 0.200 & 1.00 & 1.00 & 25.0 & 1.254 & 45 \\
\hline 0.200 & 3.00 & 0.500 & 25.0 & 1.238 & 48 \\
\hline 0.200 & 3.00 & 1.00 & 25.0 & 1.313 & 49 \\
\hline 0.0200 & - & - & 40.0 & 1.000 & 70 \\
\hline 0.200 & - & - & 40.0 & 1.056 & 64 \\
\hline 0.0200 & - & - & 55.0 & 0.993 & 67 \\
\hline 0.200 & - & - & 55.0 & 1.051 & 60 \\
\hline
\end{tabular}

These values w1ll be useful for determining the dimensionless schmldt number and the Reynolds number $(17)$. The Schmidt number is of ten used in calculations involving turbulent flow and the Reynolds number is used in approximations of fluid flow.

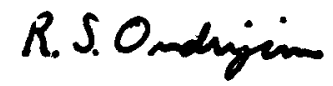

R. S. Ondrejcin Analytical Chemistry Division 


\section{BIBLIOGRAPHY}

1. Saddington, K. The Self-Diffusion of Uranium Ions in Solution. Atomic Energy Research Establishment, Harwe11, Berkshire,

England. Research and Development Report AERE-C/R-626, 13 pp. (December 1950).

2. Hahn, H. T. Self-Diffusion of Uranyl Ion and the Uranium Tributy 1 Phosphate Complex. Hanford Atomic Products Operations, Richland, Wash. AEC Research and Development Report HW-31803, $20 \mathrm{pp}$. (July 1954).

3. Lewis, J. B. Some Determinations of L1quid Phase Diffusion Coefficients Using an Improved Diaphragm Cell. Atomic Energy Research Establishment, Harwell, Berkshire, England, Research and Development Report AERE CE/R-1120, 16 pp. (November 1954).

4. Hammond, B. R. and R. H. Stokes. "Diffusion in Binary Liquid Mixtures - Part 2". Trans. Faraday Soc. 51, 1641-9 (1955).

5. Hammond, B. R. and R. H. Stokes. "Diffusion in Binary Liquid M1xtures - Part 3". Trans. Faraday Soc. 52, 781-6 (1956).

6. Glasstone, S., et al. The Theory of Rate Processes. Ist Ed. New York: McGraw-H111, pp. 477-551 (1941).

7. Anderson, J. S. and K. Saddington. "The Use of Radioact1ve Isotopes in the Study of the Diffusion of Ions in Solution". J. Chem. Soc. (London) 1949, pp. S381-6.

8. Gosting, I. G., et al. "Equipment and Experimental Methods for Interference Diffusion Studies". Rev. Sc1. Instr. 20, 209-15 (1949).

9. Huizenga, J.R., et al. "Electrolytic Properties of Aqueous Solutions of Polyacrylic Acld and Sodium Hydroxide. II. Diffusion Experiments Using Radioactive Sodium". J.Am. Chem. Soc. 72, 4228-32 (1950).

10. Nielsen, J.M., et al. "The Self-diffusion Coefficients of the Ions in Aqueous Sodium Chloride and Sodium Sulfate at $25^{\circ}$. I. Am. Chem. Soc. 74, 446-51 (1952).

11. Smith, I. E. and J. A. Storrow. "Diffusion Coefficients of Ethanol in Aqueous Solutions". J.Appl. Chem. 2, 225-35 (1952).

12. Stokes, R. H. "An Improved Diaphragm-celi for Diffusion Studies, and Some Tests of the Method". J.Am. Chem. Soc. 72 , 763-7 (1950). 
13. Langsworth, L. G., et al. "The Diffusion of Electrolytes and Macromolecules in Solution". Ann. N. Y.Acad. Sc1. 46, 211-346 (1945).

14. Stokes, R. H. "Electrophoretic Contributions to the Diffusion of Electrolytes". J. Am. Chem. Soc. 75, 2533-4 (1953).

15. MacDonald, C. M. Precise Determination of Uranium in Uranyl Nitrate-Aluminum Nitrate Solitions. E. I. du Pont de Nemours \& Co., Savannah River Laboratory, Aiken, S. C. AEC Research and Development Report DP-503, 8 pp. (July 1960).

16. Cole, A. F. W. and A. R. Gordon. "The Diffusion of Copper Sulfate in Aqueous Solutions of Sulfuric Acld". J. Phys. Chem. 40, 733-7 (1936).

17. Chemlcal Englneers' Handbook. J. H. Perry, ed. 3rd Ed. New York: McGraw-H111, pp. 375, 543, 1224-7 (1950). 